\title{
Angiospermas aquáticas da Área de Proteção Ambiental (APA) do Cariri, Paraíba, Brasil
}

Aquatic angiosperms in the Environmental Protection Area (EPA) of Cariri, Paraíba state, Brazil

\author{
Elimar Alves de Lima ${ }^{1}$, Hermes de Oliveira Machado-Filho ${ }^{1}$ \& José Iranildo Miranda de Melo ${ }^{2,3}$
}

\begin{abstract}
Resumo
A Área de Proteção Ambiental (APA) do Cariri está localizada entre os municípios de Boa Vista e Cabaceiras, estado da Paraíba, Nordeste do Brasil. Esta APA apresenta microhabitats variados, dentre os quais se destacam os corpos aquáticos. O presente estudo compreende o levantamento das angiospermas aquáticas na APA do Cariri, onde foram registradas 29 espécies distribuídas em 22 gêneros e 14 famílias, sendo Cyperaceae a que apresentou maior riqueza específica (nove spp.). Nesse trabalho são apresentadas descrições, ilustrações, dados de distribuição, floração e/ou frutificação, além de uma chave de identificação para as espécies registradas na APA.
\end{abstract}

Palavras-chave: macrófitas, angiospermas, corpos aquáticos, caatinga, florística.

\begin{abstract}
The Cariri Environmental Protection Area (AEP) is located in the municipalities of Boa Vista and Cabaceiras, Paraíba state, Northeast Brazil. It has several microhabitats, of which water bodies stand out. The present study comprises the survey of the aquatic angiosperms in the Cariri EPA, where 29 species distributed in 22 genera and 14 families were registered, with Cyperaceae as the family with the most species (9 spp.). Descriptions, illustrations, distribution, flowering and/or fruiting data plus a key for taxonomic separation of the species registered in the EAP are presented in this work.
\end{abstract}

Key words: macrophytes, angiosperms, water bodies, caatinga vegetation, floristics.

\section{Introdução}

A Caatinga é o mais negligenciado dos ecossistemas brasileiros, nos mais diversos aspectos, embora sempre tenha sido um dos mais ameaçados em decorrência de sua extrema fragilidade, de vários anos de exploração e uso inadequado dos seus solos e recursos naturais (Andrade-Lima 1981; Velloso et al. 2002; Alves 2007; Barbosa et al. 2007).

Nesse cenário, destacam-se os corpos aquáticos de um modo geral, que são ainda pouco estudados sob diferentes aspectos, inclusive do ponto de vista florístico-taxonômico (Agostinho et al. 2005). No entanto, nos últimos anos o estudo das macrófitas aquáticas tem se intensificado, tornando disponível dados sobre composição florística, taxonomia e estrutura destas comunidades em diversas regiões brasileiras (Camargo et al. 2003; Bove et al. 2003; Martins et al. 2008; Pivari et al. 2008a, b). Por outro lado, ainda há lacunas em seu conhecimento na Região Nordeste do Brasil (Henri-Silva et al. 2010; Campelo et al. 2012; Moura-Júnior et al. 2013), especialmente no estado da Paraíba onde inexistem estudos enfocando exclusivamente este grupo, tanto do ponto de vista ecológico quanto florístico-taxonômico.

As hidrófitas compõem a principal fonte de produção de biomassa em ecossistemas aquáticos (Scremin-Dias et al. 1999), e sua ocorrência garante alimento e abrigo para animais (peixes e invertebrados,

\footnotetext{
${ }^{1}$ Universidade Estadual da Paraíba, Programa de Pós-Graduação em Ecologia e Conservação, Av. das Baraúnas 351, Campus, Bairro Universitário, 58429-500, Campina Grande, PB, Brasil.

${ }^{2}$ Universidade Estadual da Paraíba, Centro de Ciências Biológicas e da Saúde, Depto. Biologia, Av. das Baraúnas 351, Campus, Bairro Universitário, 58429-500, Campina Grande, PB, Brasil.

${ }^{3}$ Autor para correspondência: tournefort@gmail.com
} 
principalmente), além de auxiliar na estabilidade da margem dos corpos aquáticos. As plantas aquáticas têm ainda um importante papel na ciclagem de nutrientes e no intercâmbio entre o meio terrestre e o meio aquático, realizando uma filtragem dos nutrientes bentônicos e dissolvidos na água (Leite 2001).

Faz-se oportuno mencionar que as abordagens de cunho florístico-taxonômico são de fundamental importância para a caracterização dos sistemas aquáticos continentais, sobremaneira, no semiárido brasileiro, onde a composição de comunidades de macrófitas aquáticas ainda é escassamente conhecida.

Dentro deste cenário encontra-se o Cariri, uma microrregião do estado da Paraíba inserida no domínio do semiárido, localizada na franja ocidental do planalto da Borborema. Segundo Barbosa et al. (2007), a flora do Cariri Paraibano não é tão pobre quanto se considerava, e em áreas mais conservadas pode ser bem diversa e rica.

Nesse contexto, o presente estudo teve por objetivos: a) identificar a riqueza de angiospermas aquáticas na Área de Proteção Ambiental (APA) do Cariri, estado da Paraíba; b) elaborar uma chave para a identificação das espécies; c) prover descrições taxonômicas e detectar as formas biológicas das espécies registradas nesse trabalho.

\section{Materiais e Métodos}

A Área de Proteção Ambiental (APA) do Cariri, criada pelo decreto $\mathrm{N}^{\circ} .25 .083$, de 8 de junho de 2004 (Paraíba, 2013), abrange 18.560 ha e está localizada entre os municípios de Boa Vista e Cabaceiras, Paraíba, e encontra-se inserida em uma região em franco estado de desertificação no semiárido brasileiro (Souza et al. 2010). Apresenta elevado déficit hídrico e índice pluviométrico que não ultrapassa $600 \mathrm{~mm} / \mathrm{ano}$ (Moreira 1988) e, apesar da limitada disponibilidade hídrica, o represamento de cursos d'água temporários ou acúmulo de água em fendas de rochas resultou na formação de áreas periodicamente indundadas (Fig. 1a-b), que permitem o desenvolvimento da vegetação aquática, alvo deste estudo.

Foram consideradas plantas aquáticas os vegetais visíveis a olho nu, cujas partes fotossintetizantes estejam em parte ou totalmente submersas, ou ainda flutuando em água doce ou salobra e tal situação deverá ser permanente ou ocorrer durante alguns periodos do ano (Cook 1996).

As amostras de plantas foram coletadas quinzenalmente em áreas temporariamente inundadas, Fazenda Salambaia e Sítio Bravo, ambas localizadas dentro da APA do Cariri, no período entre Outubro/2009 e Fevereiro/2011, abrangendo uma estação seca e outra chuvosa. As plantas foram classificadas segundo a forma biológica em: flutuantes livres, flutuantes fixas, submersas livres, submersas fixas, emergentes e anfíbias (Irgang \& Gastal-Jr. 1996), com base em observações feitas durante a realização dos trabalhos de campo. A espécie Lemna minuta Kunth. não foi encontrada em estádio reprodutivo durante a execução dos trabalhos de campo na área de estudo e, por esta razão, a descrição das estruturas reprodutivas foi baseada no trabalho de Pott \& Cervi (1999).

Os espécimes foram coletados e herborizados com base nas técnicas taxonômicas usuais (Fidalgo \& Bononi 1989) e incorporados à coleção do Herbário Manuel de Arruda Câmara (ACAM), Campus I, da Universidade Estadual da Paraíba (UEPB) e do Herbário Jayme Côelho de Moraes (EAN), Campus II, da Universidade Federal da Paraíba (UFPB).

Para identificação das espécies foram utilizadas flórulas, floras regionais, revisões taxonômicas e outras obras de cunho florístico e florístico-taxonômico (Haynes \& Holm-Nielsen 1994; Araújo \& Longhi-Wagner 1996; Luceño et al. 1997; Zardini \& Raven 1997; Pott \& Cervi 1999; Gomes 2000; Anderson \& Amaral 2005; Gil \& Bove 2007; Amaral et al. 2008; Souza \& Giulietti 2009; Matias 2010), bem como exemplares depositados nos herbários paraibanos: Lauro Pires Xavier (JPB) e Jayme Coelho de Moraes (EAN) (acrônimos dos herbários segundo Thiers (2010), que foram preferivelmente identificados e ou confirmados por especialistas nos respectivos grupos taxonômicos. As famílias listadas estão de acordo com o APG III (2009).

Foram elaboradas descrições e chave para identificação das espécies, além de ilustrações. Também são apresentados comentários e dados sobre a distribuição geográfica das espécies, os quais foram obtidos na literatura especializada, complementados pelos dados disponibilizados em Forzza et al. (2012) e na base de dados $\mathrm{W}^{3}$ Tropicos (Tropicos 2012).

\section{Resultados e Discussão}

$\mathrm{Na}$ área de estudo foram registradas 29 espécies pertencentes a 22 gêneros e 14 famílias, sendo Cyperaceae a mais representativa (9 spp.), seguida de Pontederiaceae (3 spp.), Alismataceae 

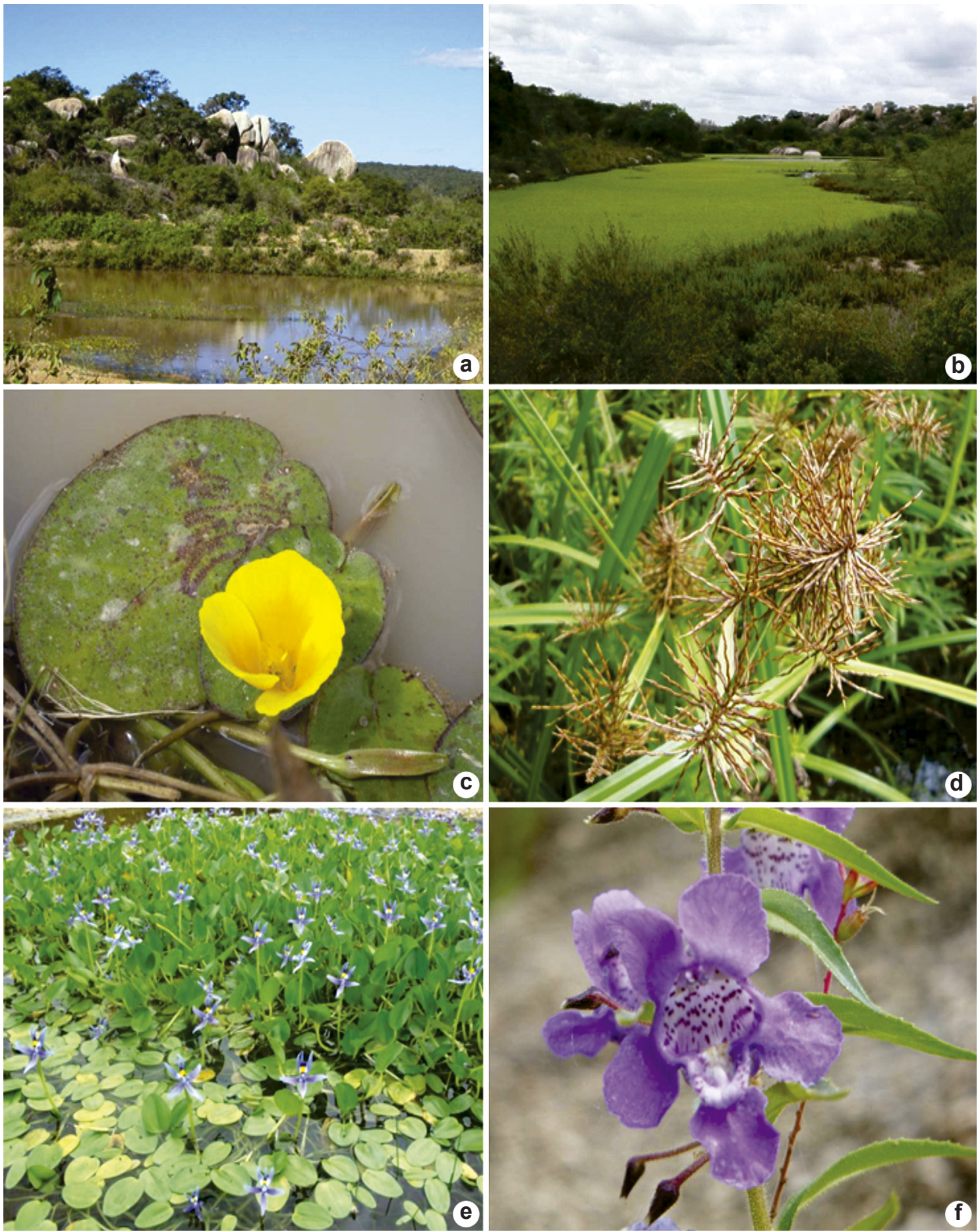

Figura 1 - Ambientes e espécies de hidrófitas fanerogâmicas da APA do Cariri, Paraíba, Brasil. a-b. corpos aquáticos da área de estudo, Sítio Bravo e Fazenda Salambaia. c. Hydrocleys modesta. d. Cyperus odoratus. e. Heteranthera limosa ao fundo. f. Angelonia biflora.

Figure 1 - Environments and hydrophytes species of the Cariri's APA, Paraíba state, Brazil. a-b. water bodies of the study area, Sítio Bravo and Salambaia Farm. c. Hidrocleys modesta. d. Cyperus odoratus. e. Heteranthera limosa in the background. f. Angelonia biflora . 
(2 spp.), Araceae (2 spp.), Asteraceae (2 spp.), Onagraceae (2 spp.) e Plantaginaceae (2 spp.), enquanto as demais famílias (7) apresentaram uma espécie cada. A seguir é apresentada uma chave para identificação das espécies, bem como descrições taxonômicas, dados de distribuição geográfica, floração e ou frutificação e comentários para as mesmas.

\section{Chave de identificação para as espécies de macrófitas aquáticas registradas na APA do Cariri, PB, baseada em caracteres vegetativos e reprodutivos:}

1. Monocotiledôneas.

2. Plantas diminutas ou com folhas em rosetas.

3. Folhas em roseta, esponjosas

4. Pistia stratiotes

3. Folhas nunca em roseta, nem esponjosas

3. Lemna minuta

2'. Plantas de maior porte, folhas não dispostas em rosetas.

4. Flores reunidas em espiguetas.

5. Escapo cilíndrico.

6. Folhas reduzidas à bainha.

7. Escapo septado.

8. Ápice da bainha oblíquo

15. Eleocharis interstincta

8'. Ápice da bainha truncado

13. Eleocharis elegans

7'. Escapo não septado

14. Eleocharis geniculata

6'. Folhas desenvolvidas

9. Inflorescências monocéfalas

12. Cyperus uncinulatus

9'. Inflorescências espiciformes

16. Fimbristylis cymosa

5'. Escapo trígono.

10. Inflorescências espiciformes

17. Pycreus macrostachyos

10'. Inflorescências em antelódios.

11. Antelódios simples, formados por raios primários

10. Cyperus odoratus

11'. Antelódios compostos.

12. Folhas de comprimento superior ao do escapo, lâmina lanceolada

9. Cyperus ligularis

12 '. Folhas de comprimento pouco menor que o escapo, lâmina linear

11. Cyperus surinamensis

4'. Flores reunidas em outros tipos de inflorescências.

13. Gineceu dialicarpelar.

14. Flores de corola alva

1. Echinodorus subalatus

14'. Flores de corola amarela

2. Hydrocleys modesta

13'. Gineceu gamocarpelar.

15. Flores de corola alva, actinomorfas

18. Apalanthe granatensis

15'. Flores azuis ou róseas, zigomorfas.

16. Folhas de lâmina cordiforme; inflorescências paniculadas, multifloras (mais de 50); anteras de tamanhos iguais entre si

25. Eichhornia paniculata

16'. Folhas de lâmina oval a oblonga; inflorescências de outros tipos, paucifloras (no máximo 15); anteras de tamanhos diferentes entre si.

17. Lâmina foliar oval-oblonga, de base truncada; inflorescências unifloras

26. Heteranthera limosa

17'. Lâmina foliar oblonga, de base cordada; inflorescências bifloras.

27. Heteranthera oblongifolia

1'. (Eu-)Dicotiledôneas.

18. Flores dialipétalas.

19. Flores solitárias, muito grandes e vistosas

20. Nymphaea ampla 
19'. Flores reunidas em inflorescências

20. Corola alva; ginóforo presente

7. Tarenaya spinosa

20'. Corola amarela; ginóforo ausente (ovário ínfero).

21. Flores tetrâmeras; estames-8; cápsula tetragonal

22. Ludwigia octovalvis

21'. Flores pentâmeras; estames-10; cápsula subcilíndrica

21. Ludwigia leptocarpa

18'. Flores gamopétalas.

22. Flores reunidas em capítulos; anteras conatas.

23. Folhas sésseis; brácteas lanceoladas; flores alvas

23'. Folhas pecioladas; brácteas obovais a oblanceoladas; flores alaranjadas

6. Eclipta prostrata

5. Acmella uliginosa

22'. Flores nunca reunidas em capítulos; anteras livres entre si 24

24. Corola alva de lobos fimbriados

19. Nymphoides indica

24'. Corola nunca alva nem de lobos fimbriados 25

25. Flores zigomorfas, corola azul ou com variações desta coloração.

26. Cálice dialissépalo.

27. Ramos viscosos; corola azul a arroxeada; estames 4

24. Stemodia maritima

27'. Ramos nunca viscosos; corola azul-violáceo, com nectários; estames 2 .......

23. Angelonia biflora

26'. Cálice gamossépalo

29. Stachytarpheta elatior

25'. Flores actinomorfas, corola rósea ou amarelo-esverdeada.

28. Plantas latescentes; corola rósea

8. Ipomoea carnea

28'. Plantas sem látex; corola amarelo-esverdeada 28. Nicotiana glauca

\section{Alismataceae}

1. Echinodorus subalatus (Mart.) Griseb., Cat. Pl. Cub.: 218. 1866.

Ervas emergentes, ca. $80 \mathrm{~cm}$ alt.; ramos triangulares a cilíndricos, pubescentes. Folhas simples, emersas; pecíolo 6,3-35 × 0,5-2 cm; lâmina $8,7-10,7 \times 4,3-5,8 \mathrm{~cm}$, coriácea, oval a elíptica, ápice acuminado a agudo, margem lobada a sinuosa, base atenuada. Tirso; escapo 31,7-45 cm compr., costelado; brácteas 12-20, lanceoladas. Flores 3, unissexuadas, actinomorfas; cálice dialissépalo, sépalas 3, 1,2-1,4 × 1,5-2,5 $\mathrm{cm}$, elípticas; corola dialipétala, alva, pétalas 3 , triangulares; estames 12 , filetes $1-2,2 \mathrm{~cm}$ compr., anteras 1,7-2 mm compr., deiscência longitudinal; gineceu dialicarpelar, carpelos numerosos (mais de 20). Fruto não visto.

Material examinado: Boa Vista, Sítio Bravo, 31.X.2009, fl., R.T.S. Matias et al. 5 (ACAM, EAN).

Echinodorus subalatus ocorre na América Central e Brasil (Haynes \& Holm-Nielsen 1994) e, no Brasil, distribui-se pelas Regiões Norte, Nordeste, Centro-Oeste e Sudeste (Matias et al. 2013). É citada pela primeira vez para o estado da Paraíba no presente estudo. Na APA do Cariri foi encontrada florida em outubro. Esta espécie pode ser reconhecida, principalmente, por apresentar flores de corola dialipétala e gineceu dialicarpelar, constituído por mais de 20 carpelos.

2. Hydrocleys modesta Pedersen, Bot. Tidskr. 57: 39. 1961.

Fig. 1c, 3d-i

Ervas flutuantes livres, ca. $50 \mathrm{~cm}$ alt.; estolões até $30 \mathrm{~cm}$ compr.; ramos quadrangulares, glabros, castanhos a verdes, lustrosos. Folhas simples, rosuladas; pecíolo ca. 1-14,5 cm compr., glabro; lâmina ca. 2,6-3,4 × 1,9-3,6 cm, papirácea, oval, elíptica a orbicular, ápice arredondado, margem inteira, base cordada, pubescente, acródroma. Umbela ou reduzida a uma flor, ca. 0,7-1 ×0,9-1,6 cm; escapo 3-6 cm compr.; brácteas lanceoladas, ca. $2 \times 0,4 \mathrm{~cm}$. Flores 3, bissexuadas, actinomorfas; cálice dialissépalo, sépalas 3, 1,4-2,4 × 0,6-0,8 $\mathrm{cm}$, elípticas; corola dialipétala, amarela, ca. 8-20 cm compr., pétalas 3 , ovais a orbiculares; estames 3-6, didínamos, filetes 3-5 $\mathrm{mm}$ compr., anteras 1-2 cm compr.; gineceu dialicarpelar, carpelos 4 . Fruto folículo, 6-7 mm compr.

Material examinado: Boa Vista, Sítio Bravo, 31.X.2009, fl. e fr., R.T.S. Matias et al. 6 (ACAM, EAN); 3.III.2010, fl., H.O. Machado-Filho 40 (ACAM, EAN).

Hydrocleys modesta ocorre desde o CentroLeste brasileiro até o sudoeste da Argentina associada a pequenos lagos e rios (Haynes \& 
Holm-Nielsen 1992). De acordo com Sakuragui \& Lopes (2013), no Brasil a espécie distribui-se nos estados de Pernambuco, Piauí, Mato Grosso, Minas Gerais e Rio de Janeiro. Nesse trabalho, está sendo referida pela primeira vez para o estado da Paraíba. Pode ser facilmente reconhecível pelos ramos, quadrangulares, glabros, castanhos a verdes, lustrosos, e pelas flores de corola amarela portando gineceu dialicarpelar.

\section{Araceae}

3. Lemna minuta Kunth, Nov. Gen. Sp. (Quarto Ed.) 1: 372. 1815.

Ervas flutuantes livres; raiz ca. 9,5 mm compr. Folhas simples; lâmina 2-3,9 × 1,6-2,8 $\mathrm{mm}$, membranácea, oboval, levemente assimétrica na base, nervura geralmente ausente, se presente, pouco aparente e curta em relação à fronde, até ca. 2/3 da base da fronte, raras papilas na linha mediana no lado superior da fronde, 1-2 camadas de aerênquima no mesófilo. Flores em 2 cavidades laterais, ovário $0,2-0,4 \mathrm{~mm}$ compr., estilete persistente. Fruto exserto, ca. 0,6 $\times 0,3 \mathrm{~mm}$.

Material examinado: Boa Vista, Sítio Bravo, 31.X.2009, R.T.S. Matias et al. 8 (ACAM, EAN).

Lemna minuta ocorre em zonas temperadas e subtropicais da América (Amaral et al. 2008), tendo sido introduzida na Europa e Ásia oriental (Pott \& Cervi 1999). No Brasil, essa espécie é frequente nas Regiões Centro-Oeste e Sudeste (Amaral et al. 2008). Na APA do Cariri foi coletada com flores e frutos em outubro. Esta espécie caracteriza-se, principalmente, pela nervura, quando presente, pouco aparente e curta em relação ao tamanho da fronde.

\section{Pistia stratiotes L., Sp. Pl. 2: 963. 1753.}

Ervas flutuantes livres ou fixas em águas rasas, estoloníferas; raízes adventícias, 16-20 cm compr., pilosas, coifa desenvolvida. Folhas simples, rosuladas, sésseis a subsésseis; lâmina ca. $8,2 \times 4,6 \mathrm{~cm}$, esponjosa, geralmente oboval, ápice arredondado a retuso, margem inteira, vilosa, nervuras 5-7 proeminentes. Espádice ca. 1,3 cm compr., envolvida por espata alva, espata ca. $8 \mathrm{~mm}$ compr., externamente pilosa. Flores masculinas no ápice da espádice, filetes fundidos em coluna, anteras livres, amarelas; flores femininas na base, ovário oblíquo ao eixo da espata, carpelo 1, estigma curto. Fruto não visto.

Material examinado: Boa Vista, Fazenda Salambaia, 15.X.2011, fl., H.O. Machado-Filho 175 (ACAM, EAN).
Pistia stratiotes é uma espécie cosmopolita, ocorrendo nas margens de rios e em lagoas, estando amplamente distribuída nas regiões tropicais e subtropicais (Silva 1981). Encontrada com flores em outubro. A espécie pode ser prontamente reconhecida pelas folhas rosuladas esponjosas portando 5-7 nervuras proeminentes.

\section{Asteraceae}

5. Acmella uliginosa (Sw.) Cass., Dict. Sc. Nat. 24(2): 331. 1822.

Ervas emergentes, eretas, ca $40 \mathrm{~cm}$ alt.; ramos cilíndricos, glabros. Folhas simples, opostas; pecíolo 3-5 mm compr.; lâmina $1,1-5 \times 0,3-2,5$ $\mathrm{cm}$, membranácea, lanceolada, ápice agudo, margem inteira, base atenuada a obtusa, estrigosa. Capítulos radiados, 6-8 × 5-7 mm diâm., conoidais, formando dicásios; pedúnculo 2,2-4,5 cm compr.; brácteas unisseriadas, $2-3 \times 0,6 \mathrm{~mm}$, foliáceas, obovais a oblanceoladas, glabras, margem ciliada, ápice agudo. Flores glabras; corola gamopétala, alaranjada, tubulosa; estames 5 , anteras conatas; ovário ínfero, carpelos 2 . Fruto cipsela, ca. $1,7 \mathrm{~cm}$ compr., pápus 2-aristado, amarronzado.

Material examinado: Boa Vista, Sítio Bravo, 15.IV.2011, fl., H.O. Machado-Filho et al. 176 (ACAM, EAN).

Acmella uliginosa é considerada comum na América Latina, ocorrendo na Venezuela, Guiana, Suriname, Brasil e em área disjunta, na Índia (Silva $\&$ Santos 2010). Na APA do Cariri foi encontrada florida em abril. Esta espécie pode ser facilmente reconhecida por apresentar capítulos conoidais, formando dicásios, com brácteas obovais a lanceoladas e flores de corola alaranjada.

6. Eclipta prostrata (L.) L., Mant. Pl. 2: 286. 1771.

Subarbustos emergentes, semi-prostrados, ca. $40 \mathrm{~cm}$ alt.; ramos angulosos, estriados, com tricomas esbranquiçados esparsos. Folhas simples, opostas, sésseis; lâmina $6-12,1 \times 0,3-2,5 \mathrm{~cm}$, membranácea, lanceolada, ápice agudo, margem serreada, base cuneada. Capítulos radiados, solitários, 0,8-1,2 cm diâm.; pedúnculo $2-4 \mathrm{~cm}$ compr.; brácteas 2-seriadas, 5-7 mm compr., lanceoladas, ápice acuminado, margem ciliada. Flores glabras; corola gamopétala, alva, tubulosa; estames 5, anteras conatas; ovário ínfero, carpelos 2. Fruto cipsela, ca. $1 \mathrm{~mm}$ compr., fusiforme, portando pequenos ganchos.

Material examinado: Boa Vista, Sítio Bravo, 3.VIII.2010, fl., H.O. Machado-Filho et al. 98 (ACAM, EAN). 
Eclipta prostrata ocorre associada às regiões temperadas e tropicais e, no Brasil, foi registrada nas Regiões Norte, Nordeste, Sudeste e Sul (Amaral et al. 2008). Na APA do Cariri foi encontrada em alagados associados a afloramento rochoso, sendo coletada com flores em agosto. A espécie caracterizase morfologicamente por possuir folhas sésseis, brácteas lanceoladas e flores de corola alva.

\section{Capparaceae}

7. Tarenaya spinosa (Jacq.) Raf., Enum. Syst. Pl.: 26. 1760 .

Subarbustos anfíbios, emergentes, ca. 1,5 $\mathrm{m}$ alt.; ramos viscosos; armados, pilosos. Folhas compostas, digitadas, alternas, com estípulas; lâmina ca. $12 \times 15 \mathrm{~cm}$, papirácea, 5-7 folíolos estes lanceolados, ambas as faces recobertas por tricomas tectores, ápice agudo, margem denteada. Corimbo terminal, ca. $6 \mathrm{~cm}$ compr.; brácteas foliáceas, cordiformes. Flores vistosas, zigomorfas; cálice esverdeado, persistente; cálice dialissépalo, sépalas ca. $5 \times 2 \mathrm{~mm}$; corola dialipétala, alva, pétalas ca. 1 $\times 0,8 \mathrm{~cm}$, unguiculadas; estames 6 , anteras ca. $5 \mathrm{~mm}$ compr., amarelas; gineceu dialicarpelar, ginóforo presente, ovário súpero, carpelos 2 . Fruto cápsula, ca. $14 \mathrm{~cm}$ compr., deiscência longitudinal.

Material examinado: Boa Vista, Sítio Bravo, 20.VII.2010, fl., H.O. Machado- Filho et al. 19 (ACAM, EAN); 15.IV.2011, fl., H.O. Machado-Filho 122 (ACAM, EAN).

Tarenaya spinosa apresenta ampla distribuição no Brasil, ocorrendo associada a áreas úmidas (Amaral et al. 2008). Na APA do Cariri foi encontrada florida em julho. Esta espécie caracteriza-se morfologicamente por apresentar flores dialipétalas reunidas em corimbos terminais, de corola alva, zigomorfa, e pela presença do ginóforo.

\section{Convolvulaceae}

8. Ipomoea carnea Jacq., Enum. Syst. Pl.: 13. 1760.

Arbustos emergentes, eretos, ca. $2 \mathrm{~m}$ alt.; ramos glabros, lactescentes. Folhas simples, alternas, helicoidais; pecíolo 3-4 cm compr.; lâmina ca. $10 \times 13 \mathrm{~cm}$, cordada, glabrescente, ápice mucronado, margem lisa, base cordada. Dicásio terminal, corimbiforme, $12-13,5 \mathrm{~cm}$ compr. Flores vistosas, pedunculadas, actinomorfas; cálice dialissépalo, persistente, sépalas 5, ovais, glabras; corola gamopétala, rósea, com fauce e tubo magenta a púrpura, interplicas triangulares, infundibuliforme; estames 5, heterodínamos; estigmas biglobosos, ovário súpero, carpelos 2 . Fruto não visto.
Material examinado: Boa Vista, Sítio Bravo, 15.IV.2011, fl., H.O. Machado- Filho et al. 182 (ACAM, EAN).

Ipomoea carnea apresenta-se amplamente distribuída na América Latina, tendo sido registrada na África (Mobot 2012). No Brasil, ocorre espontaneamente em todo o território, sendo introduzida como planta ornamental (Amaral et al. 2008). Na APA do Cariri foi encontrada com flores em abril. Esta espécie é reconhecível por apresentar ramos lactescentes, flores gamopétalas, actinomorfas, de corola rósea com fauce e tubo variando de magenta a púrpura.

\section{Cyperaceae}

9. Cyperus ligularis L., Syst. Nat. (ed. 10) 2: 867. 1759.

Ervas anfíbias, cespitosas, 0,7-1 m alt., rizomatosas; rizoma curto. Escapo obtusamente trígono, não septado; catafilos vináceos 1-6 $\mathrm{mm}$ compr., ápice acuminado. Folhas simples, invaginantes, comprimento superior ao do escapo; lâmina $60-80 \times 0,6-0,8 \mathrm{~cm}$, coriácea, lanceolada, margem serrilhada; bainha 14-36 cm compr., membranácea. Antelódio composto, laxo, 1-2,4 cm compr.; brácteas 4-6, patentes. Espigas multifloras 4-6 mm compr., subsésseis, densas; glumas férteis imbricadas, elípticas, ápice obtuso. Fruto aquênio, 1,5-0,7 cm compr., tríquetro, superfície reticulada, castanho.

Material examinado: Boa Vista, Fazenda Salambaia, 9.X.2010, fl. e fr., E.A. Lima 106 (ACAM, EAN).

Cyperus ligularis ocorre nas Antilhas, Argentina, México, Peru e Brasil (Barros 1960; Guaglianone 1996). No Brasil está registrada para os estados do Amazonas, Santa Catarina, Paraná, Paraíba, Pernambuco (Luceño et al. 1997; Hefler \& Longhi-Wagner 2012). Encontrada na área de estudo com flores e frutos em outubro. Esta espécie distingue-se prontamente das demais espécies congêneres registradas na área de estudo por apresentar folhas mais longas que o escapo.

10. Cyperus odoratus L., Sp. Pl. 1: 46. 1753.

Fig. 1d.

Ervas anfíbias, não-cespitosas, rizomatosas, 60-90 cm alt.; rizomas curtos. Escapo obtusamente trígono; catafilos vináceos, ca. 4-6 mm compr., ápice agudo. Folhas simples, invaginantes; lâmina $25-35 \times 0,5-0,7 \mathrm{~cm}$, cartácea, linear, margem serrilhada; bainha 13-28 cm compr.; lígula ausente. Antelódio simples, raios primários, 5,3-6,2 cm compr. Espigas multifloras, subsésseis, 
fragmentadas em unidades para dispersão do fruto, 0,6-1,5 cm compr.; glumas férteis imbricadas. Fruto aquênio, ca. $2 \mathrm{~mm}$ compr., tríquetro, estreitoelíptico, superfície papilosa, castanho escuro.

Material examinado: Boa Vista, Fazenda Salambaia, 25.II.2011, fl. e fr., E.A. Lima 113 (ACAM, EAN).

Cyperus odoratus distribui-se na América tropical e subtropical (Adams 1994) e, no Brasil, apresenta-se amplamente distribuída (Mobot 2012). Na área de estudo, foi encontrada com flores e frutos em fevereiro. Pode ser facilmente diferenciada das demais espécies congêneres registradas na APA do Cariri pela presença de escapo triangular e antelódios simples.

11. Cyperus surinamensis Rottb., Descr. Pl. Rar.: 20. 1772.

Ervas anfíbias, cespitosas, $20-80 \mathrm{~cm}$ alt., rizomatosas; rizomas curtos. Escapo trígono, escabro, 30-60 cm compr. Folhas simples, concentradas na base da planta, pouco menores que o escapo; lâmina ca. 14,5 ×0,3 cm, linear, plana; bainha 2,5-3,5 cm compr., ápice glabro, consistência não diferenciada do restante; lígula ausente. Antelódio composto, ca. 2,5 cm compr., no ápice do escapo; brácteas 3, ca. 5,5 ×0,2 cm. Espigueta multiflora ca. $5 \mathrm{~mm}$ compr., comprimidas lateralmente, glumas dísticas, gluma inferior fértil; flores bissexuadas. Fruto aquênio, ca. $0,8 \mathrm{~mm}$ compr., tríquetro, estipitado, castanho-escuro.

Material examinado: Boa Vista, Fazenda Salambaia, 18.III.2011, fl. e fr., E.A. Lima 16 (ACAM, EAN).

Cyperus surinamensis apresenta distribuição pantropical e no continente americano, ocorre desde o sul dos Estados Unidos, passando pelo México e América Central até a América do Sul (Chen et al. 2009; Mobot 2012). Na área de estudo foi coletada com flores e frutos em março. Esta espécie pode ser prontamente reconhecida por apresentar escapo trígono e inflorescências monocéfalas.

12. Cyperus uncinulatus Schrad. ex Nees, Fl. bras. 2(1): 23.1842.

Ervas emergentes, cespitosas, $10-20 \mathrm{~cm}$ alt., rizomatosas. Folhas simples, invaginantes; lâmina $10-12 \times 0,6-0,8 \mathrm{~cm}$, linear, margem serrilhada. Escapo cilíndrico a subcilíndrico, liso; bráctea foliácea mais longa que a inflorescência. Espiga monocéfala globosa, congesta, ca. $1,1 \mathrm{~cm}$ compr.; espiguetas plurifloras, 2-4 mm compr., comprimidas lateralmente, subsésseis; gluma ovalada, nervuras inconspícuas, ápice aristado, margem membranácea, hialina; estames 3 ; estilete trífido. Fruto aquênio, ca. 0,5 mm compr., tríquetro, superfície rugosa, castanho.

Material examinado: Boa Vista, Fazenda Salambaia, 20.VII.2010, fl. e fr., E.A. Lima 14 (ACAM, EAN); Sítio Bravo, 3.III.2010, fl. e fr., H.O. Machado-Filho 52 (ACAM, EAN).

Cyperus uncinulatus ocorre nos Estados Unidos, México, Peru, Bolívia, Chile, Argentina, Paraguai, Uruguai e, no Brasil, onde se apresenta amplamente distribuída (Araújo \& Longhi-Wagner 1996; Guaglianone 1996), em geral, associada a áreas abertas e lajedos (Alves et al. 2009). Na APA do Cariri foi encontrada com flores e frutos em março. A espécie caracteriza-se morfologicamente por apresentar escapo cilíndrico a subcilíndrico, folhas desenvolvidas e pelas inflorescências monocéfalas.

13. Eleocharis elegans (Kunth) Roem. \& Schult., Syst. Veg. 2: 150. 1817.

Ervas emergentes, cespitosas, ca. $80 \mathrm{~cm}$. alt., rizomatosas; rizomas sublenhosos, longos, entrenós curtos, cáudice ausente. Escapo cilíndrico 30-80 $\mathrm{cm}$ compr., mesma espessura da base ao ápice, septado, 1-2,5 cm entre os septos; bainha 7-13 cm compr., ápice truncado, múcron dorsal. Espigueta terminal, 1,5-3 cm compr.; gluma inferior estéril, coriácea, margem hialina estreita; glumas superiores membranáceas, disposição espiralada, margem hialina desenvolvida; estames 3 ; estilete bífido ou trífido. Fruto aquênio, ca. 1,8 $\times 0,8 \mathrm{~mm}$, tríquetro, obovóide, ocráceo.

Material examinado: Boa Vista, Fazenda Salambaia, 15.IV.2011, fl. e fr., E.A. Lima 16 (ACAM, EAN).

Eleocharis elegans ocorre desde o México até a América do Sul e, no Brasil, foi registrada para os estados de Roraima, Pará, Pernambuco, Goiás, São Paulo, Paraná, Santa Catarina e Rio Grande do Sul (Trevisan \& Boldrini 2008). Na área de estudo foi coletada com flores e frutos em abril. Esta espécie pode ser prontamente reconhecível por apresentar escapo septado e ápice da bainha truncado.

14. Eleocharis geniculata (L.) Roem. \& Schult., Syst. Veg. 2: 150. 1817.

Fig. 2a-b

Ervas anfíbias, cespitosas, ca. $15-20 \mathrm{~cm}$ alt.; rizomatosas. Escapo cilíndrico, não septado, $5,5-12 \mathrm{~cm}$ compr., esponjoso, estriado longitudinalmente. Folhas simples, reduzidas à bainha, glabras, subcoriáceas, ápice hialino íntegro; lígula ausente. Espigueta globosa, solitária, no ápice do escapo, 4-8 mm compr., glumas membranáceas em espiral, carenadas, elípticas, ápice obtuso, margem escariosa e hialina, nervura central evidente. Glumas inferiores (2-3) estéreis; 

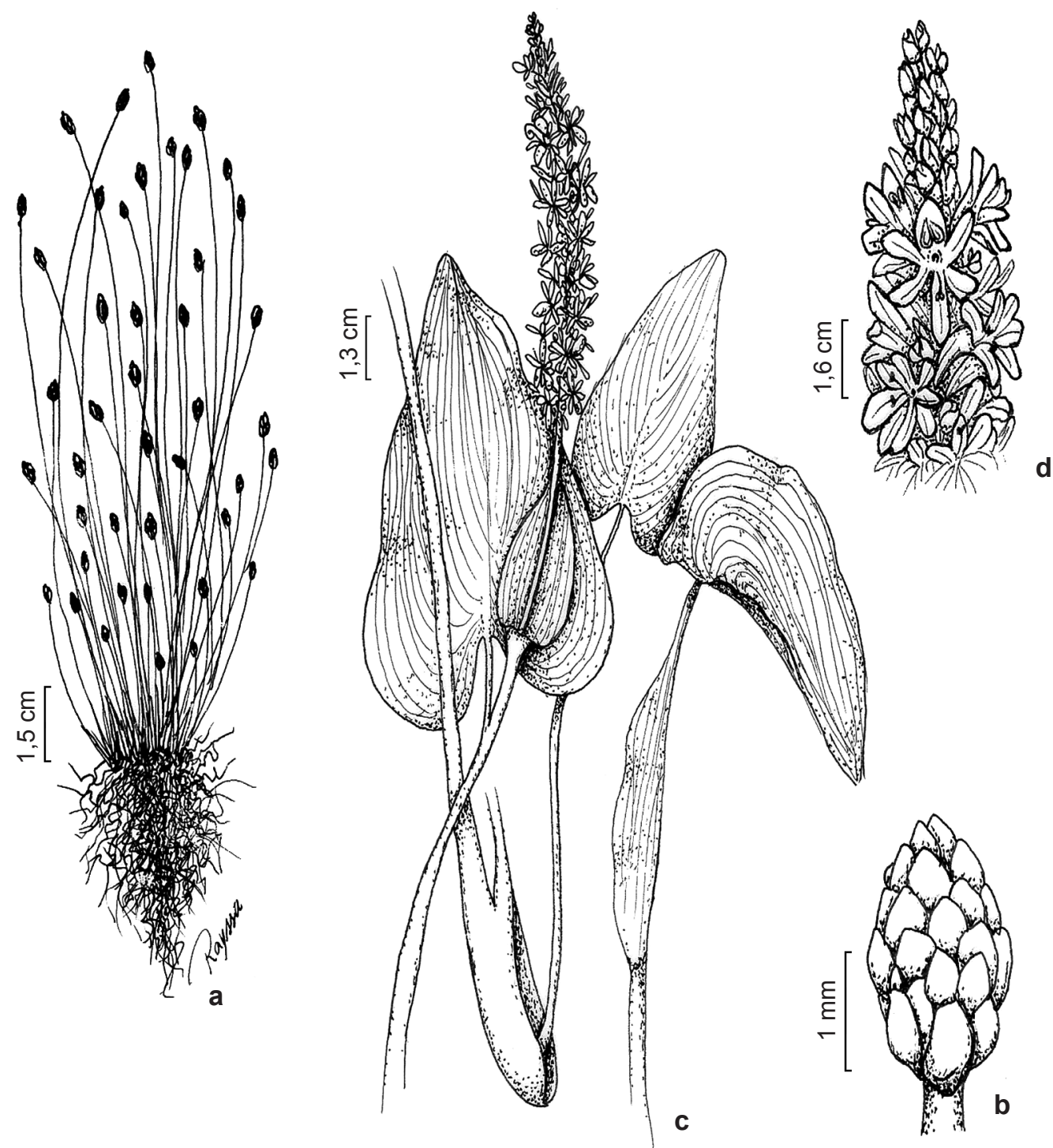

Figura 2 - a-b. Eleocharis geniculata. a. hábito; b. detalhe da inflorescência (H.O. Machado-Filho 186). c-d. Eichhornia paniculata. c. hábito; d. detalhe da inflorescência (E.A. Lima 4).

Figure 2 - a-b. Eleocharis geniculata. a. habit; b. detail of the inflorescence (H.O. Machado-Filho 186). c-d. Eichhornia paniculata. c. habit; d. detail of the inflorescence (E.A. Lima 4).

estames 3, filetes hialinos, anteras apiculadas; estigma bífido; estigmas 2, 1-1,5 mm compr. Fruto aquênio, 3-5 mm compr., lenticular, estipitado, negro.

Material examinado: Boa Vista, Fazenda Salambaia, 25.II.2011, fl. e fr., E.A. Lima 16 (ACAM, EAN); Sítio Bravo, 15.IV.2011, fl. e fr., H.O. Machado-Filho 186 (ACAM, EAN).

Eleocharis geniculata distribui-se na Índia, África do Sul, Estados Unidos da América, América Central, incluindo Antilhas, e América do Sul (Gil \& Bove 2007). No Brasil ocorre de forma generalista em todas as regiões (Gil \& Bove 2007;
Silveira \& Longhi-Wagner 2008). Na APA do Cariri foi coletada com flores e frutos em junho. A espécie pode ser facilmente reconhecível pelas folhas reduzidas à bainha e pelo escapo não septado, bem como pelas espigas globosas solitárias.

15. Eleocharis interstincta (Vahl) Roem. \& Schult., Syst. Veg. 2: 149. 1817.

Ervas emergentes, estoloníferas, cespitosas, ca. $30 \mathrm{~cm}$ alt. Escapo cilíndrico, 18-33,5 cm compr., regularmente septado, septos transversais 
não evidentes, canal de ar central, lisos. Folhas simples, reduzidas à bainha, membranáceas, 8-12,5 cm compr., castanho-avermelhadas, ápice oblíquo, acuminado. Espiga cilíndrica multiflora no ápice do escapo, 1,4-2,8 cm compr., amarela. Glumas espiraladas, não carenadas, membranáceas nas margens e coriáceas no centro; ápice obtuso, margem hialina e escariosa, nervuras longitudinais proeminentes. Gluma inferior externa estéril envolvendo quase totalmente a base da espiga; estames 3, filetes hialinos, $6 \mathrm{~mm}$ compr., anteras $3 \mathrm{~mm}$ compr.; estigma 2-3-fido, 7-8 mm compr. Fruto aquênio, 0,8-1,2 mm compr., obovóide, lenticular, castanho-amarelado.

Material examinado: Boa Vista, Fazenda Salambaia, 15.IV.2011, fl. e fr., E.A. Lima 137 (ACAM, EAN).

Eleocharis interstincta apresenta ampla distribuição no continente americano, ocorrendo desde a América do Norte até a Patagônia, sendo também registrada para a África do Sul e, no Brasil, ocorre em todas as regiões (Gil \& Bove 2007). Na área de estudo foi encontrada com flores e frutos em abril. Esta espécie caracterizase morfologicamente por apresentar folhas reduzidas à bainha, escapo septado e ápice da bainha oblíquo, acuminado.

16. Fimbristylis cymosa R. Br., Prodr.: 228. 1810.

Ervas anfíbias, cespitosas, ca. $30 \mathrm{~cm}$ alt., rizomatosas; rizomas curtos. Escapo cilíndrico, ca. $30 \mathrm{~cm}$ alt. Folhas simples, dispostas em roseta na base da planta; lâmina ca. $13 \times 0,3$ $\mathrm{cm}$, membranácea, linear, glabra. Bainha 1,5-2,3 $\mathrm{cm}$ compr., glabra; lígula ausente. Antelódio composto, denso, espiciforme, espiguetas multifloras ca. $7 \mathrm{~mm}$ compr., cilíndricas, glumas em espiral, gluma inferior fértil; flores bissexuais, estames 2, estigmas 2, estilete glabro, bractéolas vináceas. Fruto aquênio, ca. $8 \mathrm{~mm}$ compr., lenticular, castanho.

Material examinado: Boa Vista, Fazenda Salambaia, 15.IV.2011, fl. e fr., E.A. Lima 139 (ACAM, EAN).

Fimbristylis cimosa apresenta distribuição neotropical, ocorrendo desde a América do Norte até a América do Sul (Luceño et al. 1997). No Brasil é amplamente distribuída, ocorrendo associada a ambientes salinos (Martins et al. 1999). $\mathrm{Na}$ APA do Cariri foi coletada com flores e frutos em abril. A espécie é facilmente reconhecível por apresentar escapo cilíndrico, associado às folhas desenvolvidas e às inflorescências espiciformes.
17. Pycreus macrostachyos (Lam.) J. Raynal, Kew Bull. 23: 314. 1969.

Ervas anfíbias, cespitosas, ca. $50 \mathrm{~cm}$ alt., rizomatosas; rizomas curtos. Escapo trígono, levemente escabro; bráctea mais longa que a inflorescência. Folhas simples, concentradas na base da planta; lâmina ca. $50 \times 0,5 \mathrm{~cm}$, linear. Bainha membranácea, glabra. Antelódio espiciforme, 2,8-7,4 cm compr. Espiguetas multifloras, subsésseis, comprimidas lateralmente; glumas dísticas ca. 1,6 mm compr., com margem hialina delimitada por uma faixa submarginal castanha, nervura central evidente, com múcron dorsal; gluma inferior fértil. Flores bissexuadas; estames 3; estilete bífido. Fruto aquênio, ca. 1 $\mathrm{mm}$ compr., comprimido dorsiventralmente, ornamentado, vináceo.

Material examinado: Boa Vista, Fazenda Salambaia, 5.VII.2011, fl. e fr., E.A. Lima 212 (ACAM, EAN).

Pycreus macrostachyos está distribuída na América Central (El Salvador, Honduras, Costa Rica e Panamá) e do Sul (Brasil, Paraguai, Equador) (Mobot 2012). Segundo Luceño et al. (1997) ocorre em áreas abertas e sazonalmente alagadas, associada a solos arenosos. Na APA do Cariri foi encontrada com flores e frutos em julho. Caracteriza-se morfologicamente por apresentar escapo trígono e antelódios espiciformes.

\section{Hydrocharitaceae}

18. Apalanthe granatensis (Bonpl.) Planch., Ann. Mag. Nat. Hist., ser. 2, 1: 87. 1848.

Ervas submersas fixas, caule ramificado. Folhas simples, alternas verticiladas, $8-16 \times$ 1-3 mm, sésseis; lâmina linear, glabra, ápice agudo, margem inteira. Flores solitárias, axilares, emersas, actinomorfas; cálice dialissépalo, sépalas 3, ca. $2 \mathrm{~mm}$ compr.; corola dialipétala, alva, pétalas 3 , ca. $3 \mathrm{~mm}$ compr.; estames 3 , anteras ca. 0,3 $\mathrm{mm}$ compr., rimosas; gineceu gamocarpelar, ovário ínfero. Fruto não visto.

Material examinado: Boa Vista, Fazenda Salambaia, 25.II.2011, fl., E.A. Lima 236 (ACAM, EAN).

Apalanthe granatensis apresenta distribuição neotropical, sendo encontrada praticamente em todo o Brasil (Alves-Araújo \& Maciel 2009). Observada com flor em fevereiro. Caracteriza-se morfologicamente por suas flores alvas, bissexuadas e com 3 estames e, segundo Amaral et al. (2008) apenas suas flores emergem da coluna d'água. 


\section{Menyanthaceae}

19. Nymphoides indica (L.) Kuntze, Revis. Gen. Pl. 2: 429. 1891.

Fig. 3a-c

Ervas flutuantes fixas, estoloníferas. Folhas simples, pecíolo $16-20 \mathrm{~cm}$ compr.; lâmina orbicular, reniforme, glabra, serícea, ca. $15 \times 18$ $\mathrm{cm}$, base cordada; ápice obtuso, margem inteira, base cordada. Flores solitárias ou reunidas em racemos. Flores 1,2-2,4 cm compr., pedicelo 2,5-6 cm compr., cilíndrico; cálice gamossépalo, sépalas lanceoladas, ca. 2,8 mm compr.; corola gamopétala, alva, com base amarela, lobos 5, 1,1-1,9 ×0,4 cm, fimbriados, densamente pilosa na face interna; anteras $1-2 \mathrm{~mm}$ compr., filetes $3-8 \mathrm{~mm}$ compr., estaminódios-5, fimbriados, opostos aos lóbulos das pétalas; ovário ca. $1 \mathrm{~mm}$ compr. Fruto não visto. Material examinado: Boa Vista, Sítio Bravo, 25.II.2011, fl., H.O. Machado- Filho et al. 97 (ACAM, EAN).

Nymphoides indica ocorre na África e América tropical e subtropical. No Brasil está distribuída nos estados do Ceará, Paraíba, Pernambuco, Rio Grande do Sul e São Paulo (Anderson \& Amaral 2005). Encontrada em áreas alagadiças e lênticas ou com pouca movimentação, formando grandes populações e estabelecendo-se ao longo das margens de corpos de água doce, em ambientes aquáticos de salinidade variável (Trindade et al. 2010). Encontrada florida em fevereiro. A espécie pode ser reconhecida pelas folhas reniformes e flores de corola alva com base amarela.

\section{Nymphaeaceae}

20. Nymphaea ampla (Salisb.) DC., Syst. Nat. 2: 54. 1821.

Ervas flutuantes fixas, rizomatosas. Frondes flutuantes, simples; pecíolo $60-70 \mathrm{~cm}$ compr., glabro; lâmina 26-31,2 × 24-27,8 cm, arredondada a orbicular, ápice retuso, margem denteada, base sagitada. Flores solitárias, vistosas; pedicelo ca. $40 \mathrm{~cm}$ compr., glabro; cálice dialissépalo, 6,9-7,5 cm compr., glabro; corola dialipétala, alva, 6-7 cm compr.; estames mais de 50, 2,1-3,4 cm compr., multisseriados, livres, filiformes; gineceu gamocarpelar, ovário súpero, carpelos numerosos (ca. 20). Fruto não visto.

Material examinado: Boa Vista, Fazenda Salambaia, 3.VIII.2010, fl., E.A. Lima et al. 36 (ACAM, EAN).

Nymphaea ampla distribui-se amplamente em toda a região da América continental e nas ilhas do Caribe (Mobot 2012). No Brasil, distribui-se nos estados da Bahia e Pernambuco em áreas de Caatinga e Mata Atlântica (Amaral 2013). Nesse trabalho, o estado da Paraíba é acrescentado à distribuição da espécie. Encontrada florida em agosto. Esta espécie é facilmente reconhecível por apresentar hábito de folhas flutuantes, mas caule fixo ao substrato, e pelas flores de corola alva.

\section{Onagraceae}

21. Ludwigia leptocarpa (Nutt.) H. Hara, J. Jap. Bot. 28 (10): 292. 1953.

Ervas ou subarbustos emergentes, ca. $80 \mathrm{~cm}$ alt., eretos; ramos ascendentes, estrigosos, com estrias longitudinais. Folhas simples, alternas espiraladas; lâmina 4,8-5,3 × 1,2-1,4 cm, elípticolanceolada, ápice agudo, margem inteira, ciliada, base atenuada; pecíolo 0,4-1,1 cm compr.; face adaxial glabra, tricomas adpressos na nervura central, face abaxial inteiramente pilosa. Flores solitárias, axilares, pentâmeras; cálice dialissépalo, sépalas 5, lacínios deltóides; corola dialipétala, amarela, pétalas 5, obovais; estames 10, heterodínamos, os epipétalos mais curtos; anteras extrorsas; ovário ínfero, cilíndrico, estigma globoso. Fruto cápsula, 1,2-1 × 0,2-0,3 cm, subcilíndrica, castanho-vinácea.

Material examinado: Boa Vista, Fazenda Salambaia, 5.VII.2011, fl. e fr, E.A. Lima 198 (ACAM, EAN).

Ludwigia leptocarpa está distribuída desde o sudeste dos Estados Unidos até a Argentina, ocorrendo também na África (Zardini \& Raven 1997). Encontrada com flores e frutos em julho. Diferenciase de L. octovalvis, da qual é morfologicamente relacionada, por apresentar lâmina foliar elípticolanceolada e, principalmente, pelas flores pentâmeras.

\section{Ludwigia octovalvis (Jacq.) P.H. Raven, Kew} Bull. 15: 476. 1962.

Arbustos anfíbios, até $50 \mathrm{~cm}$ alt., geralmente eretos; ramos ascendentes, estrigosos. Folhas alternas; lâmina ca. $4,5 \times 1 \mathrm{~cm}$, lanceolada, glabra, ápice acuminado, margem inteira, glabra, base atenuada; pecíolo ca. $5 \mathrm{~mm}$ compr. Flores solitárias, laterais e terminais, tetrâmeras; cálice dialissépalo, sépalas 4, lacínios lanceolados, ápice agudo; corola dialipétala, amarela, pétalas 4, obovais, ápice cuneado; estames 8 , de tamanhos diferentes, epipétalos e livres (maiores ca. $5 \mathrm{~mm}$ compr., menores ca. 2,5 mm compr.); ovário ínfero, cilíndrico, estigma globoso. Fruto cápsula, ca. $3 \mathrm{~cm}$ compr., tetragonal, dividindo-se em 8 valvas, castanho.

Material examinado: Boa Vista, Sítio Bravo, 15.VIII.2011, fl. e fr., H.O. Machado-Filho et al. 198 (ACAM, EAN). 


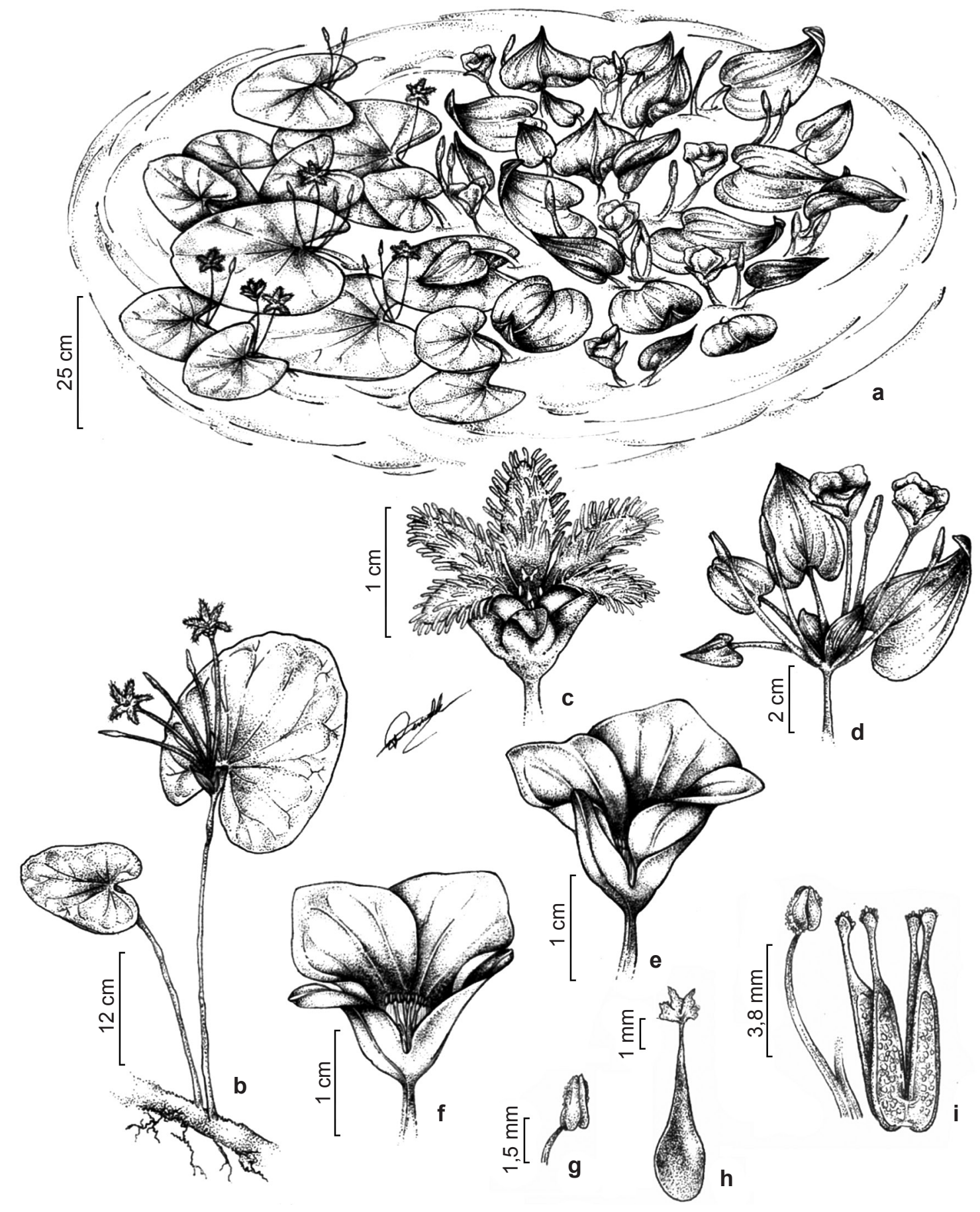

Figura 3 - a-c. Nymphoides indica. a. população natural; b. hábito; c. flor (H.O. Machado-Filho et al. 97). d-i. Hydrocleys modesta. d. inflorescência; e. flor; f. flor evidenciando androceu e gineceu; g. estame; h. pistilo; i. gineceu, destacando pistilo (H.O. Machado-Filho 40).

Figure 3 -a-c. Nymphoides indica. a. natural population; b. habit; c. flower (H.O. Machado-Filho et al. 97). d-i. Hydrocleys modesta. d. habit; e. flower; f. flower showing androecium and gynoecium; g. stamen; h. pistil; i. gynoecium, highlighting the pistil (H.O. Machado-Filho 40). 
Ludwigia octovalvis possui distribuição pantropical; ocorre na África e em toda a América e, no Brasil, distribui-se em todas as regiões (Mobot 2012). Encontrada com flores e frutos em agosto. Caracteriza-se pelo hábito arbustivo, geralmente ereto. Diferencia-se de L. leptocarpa, com a qual é morfologicamente assemelhada, por apresentar lâmina foliar distintamente lanceolada e, sobremaneira, pelas flores tetrâmeras.

\section{Plantaginaceae}

23. Angelonia biflora Benth., Prodr. 10: 254. 1795/1838.

Fig. 1f

Ervas anfíbias, eretas, 0,6-1,2 m alt.; ramos cilíndricos. Folhas sésseis opostas a subopostas, cruzadas; lâmina 3,8-5,8 ×0,8-1,1 cm, lanceolada, ápice agudo, margem serreada, base alargada, tricomas na face adaxial. Brácteas foliáceas; pedicelo 1-2 cm compr. Racemo 12-18 cm compr., terminal. Flores gamopétalas, pediceladas; cálice dialissépalo, 3-5 mm compr.; corola gamopétala, azul-violáceo, tubular, fauce branca, 1,9-2,3 cm compr., com duas bolsas elaióforos tricomáticos; estames 2, glabros; ovário súpero, carpelos 2; estiletes 2, estigmas persistentes; estames e estiletes localizados na parte superior da corola, em posição nototríbica. Fruto cápsula, ca. $8 \mathrm{~mm}$ compr., orbicular.

Material examinado: Boa Vista, Fazenda Salambaia, 20.VII.2010, fl. e fr., E.A. Lima 22 (ACAM); Sítio Bravo, 31.V.2010, fl. e fr., H.O. Machado-Filho (ACAM, EAN).

Angelonia biflora é frequentemente encontrada na caatinga, nos estados do Piauí, Ceará, Rio Grande do Norte, Paraíba e Pernambuco (Souza \& Giulietti 2009). Observadas com flores e frutos em maio e julho. Podem ser identificadas pelas flores geminadas, dispostas em racemos, podendo ser definido, e por brácteas subfalcadas e inteiras (Souza \& Giulietti 2009).

24. Stemodia maritima L., Syst. Nat. (ed. 10) 2: 1118.1759.

Ervas anfíbias, eretas, $20-50 \mathrm{~cm}$ alt., ramificadas; ramos ascendentes ou não, viscosos. Folhas opostas cruzadas, sésseis; lâmina 1,6$1,8 \times 0,5-0,9 \mathrm{~cm}$, lanceolada, ápice agudo, margem denteada, base por vezes amplexicaule, glabrescente na face abaxial, pilosa na face adaxial. Flores solitárias, axilares, zigomorfas, sésseis a subsésseis; bractéolas 3-4 mm compr., lanceoladas, ascendentes, recobrindo o cálice e, em parte, a corola; cálice dialissépalo, 3-5 × 0,5$0,7 \mathrm{~mm}$, sépalas externamante pilosas, lacínios ca. $4 \times 2 \mathrm{~mm}$, obovais; corola gamopétala, azul a arroxeada, lobos 5, ca. $6 \mathrm{~mm}$ compr.; estames 4, bífidos; ovário súpero, carpelos 2 . Fruto não visto. Material examinado: Boa Vista, Fazenda Salambaia, 3.X.2010, fl., E.A. Lima 43 (ACAM).

Stemodia maritima ocorre na América Central e Nordeste do Brasil, sobretudo próximo ao litoral, sendo encontrada também em áreas de Caatinga e campo rupestre (Souza \& Giulietti 2009). Na APA do Cariri foi encontrada florida em outubro. Pode ser reconhecida pelos ramos viscosos, folhas sésseis, corola azul a arroxeada e pelo androceu constituído por 4 estames.

\section{Pontederiaceae}

25. Eichhornia paniculata (Spreng.) Solms., Monog. Phan. 4: 530. $1882 . \quad$ Fig. 2c-d

Ervas emergentes, eretas, estoloníferas, $40-60 \mathrm{~cm}$ alt. Folhas opostas, invaginantes, com bainhas; pecíolo não inflado, $38-45 \mathrm{~cm}$ compr.; lâmina 4,7-6 × 5-6,2 cm, geralmente cordiforme, ápice agudo, margem inteira, base cordada. Panícula, terminal, 12,8-13,6 $\mathrm{cm}$ compr., multiflora (28-30); pedúnculo $0,7-1,2 \mathrm{~cm}$ compr. Flores zigomorfas, tépalas 6 , pediceladas, reunidas em grupos de 4-6; cálice dialissépalo; corola dialipétala, azul-violácea; estames 6 , livres, ca. 1,4 cm compr., anteras 1,2-1,8 mm compr., de tamanhos iguais entre si; ovário súpero, carpelos 3 . Fruto não visto. Material examinado: Boa Vista, Sítio Bravo, 20.VII.2010, fl., E.A. Lima 4 (ACAM, EAN).

Eicchornia paniculata é amplamente distribuída no Brasil, ocorrendo nos estados de Alagoas, Bahia, Ceará, Mato Grosso do Sul, Paraíba, Pernambuco, Rio de Janeiro, Rio Grande do Norte e Sergipe (Amaral et al. 2008). Ocorre preferencialmente em áreas alagadas temporárias, formando populações isoladas (Gomes 2000). Na APA do Cariri foi encontrada florida em julho. Caracteriza-se morfologicamente por apresentar hábito emergente, pecíolo com aerênquima e inflorescências em panículas terminais portando flores pediceladas.

26. Heteranthera limosa Willd., Ges. Naturf. Fr. Neue Schr. 3: 439. 1801.

Fig. 1e

Ervas emergentes, ca. $13 \mathrm{~cm}$ alt. Folhas rosuladas; pecíolo 6,5-8,2 cm compr.; lâmina 3-4 
$\times 1,7-1,9 \mathrm{~cm}$, papirácea, verde, oval a elíptica, ápice agudo a arredondado, margem inteira, base atenuada, glabra. Cimeira 6-7 mm compr., solitária, terminal. Flores solitárias, zigomorfas, pediceladas, tépalas 6; cálice dialissépalo; corola dialipétala, pétalas azuis a lilases, translúcidas; estames 3, livres, ca. 3,5 mm compr., anteras lanceoladas, deiscência longitudinal, filetes ca. $1 \mathrm{~cm}$ compr.; ovário súpero, carpelos 3 . Fruto não visto.

Material examinado: Boa Vista, Sítio Bravo, 31.X.2009, fl., R.T.S. Matias et al. 3 (ACAM, EAN).

Heteranthera limosa distribui-se em todo o continente americano, sendo amplamente distribuída no Brasil, onde se dispersa desde o estado do Pará até o Rio Grande do Sul (Gomes 2000), sendo considerada planta daninha em agroecossistemas (Lorenzi 2006). Na área de estudo foi encontrada com flores em outubro. Diferencia-se de Heteranthera oblongifolia, da qual é morfologicamente relacionada, basicamente pelas folhas rosuladas e flores azuis a lilases, reunidas em cimeira.

27. Heteranthera oblongifolia C. Mart. ex Roem. \& Schult., Syst. Veg. 7: 1148. 1830.

Ervas emergentes, $10-20 \mathrm{~cm}$ alt.; ramos prostrados. Folhas com bainhas; pecíolo 10-16 cm compr.; lâmina oval a oblonga, 2-5 × 3-6 $\mathrm{cm}$, ápice obtuso, margem inteira, base cordada. Cimeira biflora, pedúnculo 1-1,6 cm compr. Flores zigomorfas, tépalas 6 , geminadas, uma séssil e uma pedicelada, pedicelo 1,5-2 cm compr.; cálice dialissépalo; corola dialipétala, azul ou alva; estames 3, livres, anteras sagitadas; ovário súpero, carpelos 3. Fruto não visto.

Material examinado: Boa Vista, Fazenda Salambaia, 27.IX.2010, fl., E.A. Lima 134 (ACAM, EAN).

Heteranthera oblongifolia é frequentemente encontrada na Região Nordeste, sendo registrada para os estados do Piauí, Maranhão, Ceará, Rio Grande do Norte, Pernambuco e Paraíba, além do Amapá, Amazonas, Pará, Mato Grosso e São Paulo (Gomes 2000). Na área de estudo foi encontrada florida em setembro. Esta espécie pode ser facilmente reconhecível, principalmente, pelas flores alvas geminadas, sendo uma séssil e uma pedicelada.

\section{Solanaceae}

28. Nicotiana glauca Graham, Edinburgh New Philos. J. 5: 175. 1828.

Arbustos emergentes, eretos, 1,6-2 m

alt.; ramos verde-acizentados. Folhas simples, alternas; pecíolo ca. 4,9 cm compr.; lâmina ca. $7,9 \times 5,2 \mathrm{~cm}$, oval, ápice agudo, margem inteira, base cuneada a truncada, glabra, serosa. Tirso paniculado de cimas monocasiais, $8,7-11,4 \mathrm{~cm}$ compr. Flores actinomorfas, pedicelo ca. $8 \mathrm{~mm}$ compr.; cálice gamossépalo, 0,9-1,2 cm compr., tubular; corola gamopétala, amarelo-esverdeado, tubular-hipocrateriforme, $3-3,8 \times 0,5-0,7 \mathrm{~cm}$; estames 5, inclusos, 2,9-3,6 cm compr., anteras 1,5-2 mm compr.; ovário súpero, carpelos 2 . Fruto cápsula, ca. 1,2 cm compr.

Material examinado: Boa Vista, Fazenda Salambaia, 3.VIII.2010, E.A. Lima 36 (ACAM, EAN); Sítio Bravo, 20.VII.2010, fl. e fr., H.O. Machado-Filho 61 (ACAM, EAN).

Nicotiana glauca ocorre na Argentina e Bolívia, sendo amplamente distribuída nas áreas quentes e secas da América tropical, incluindo áreas de caatinga no Nordeste brasileiro (Moraes et al. 2009). Na APA do Cariri foi encontrada com flores e frutos em julho, associada às áreas mais antropizadas. A espécie apresenta hábito variável, ora emergente, ora ripário, e é facilmente reconhecível por apresentar ramos glaucos e corola tubular-hipocrateriforme amarelo-esverdeado.

\section{Verbenaceae}

\section{Stachytarpheta elatior Schrad. ex Schult.,} Mant. 1: 172. 1822.

Ervas emergentes, eretas, ca. $60 \mathrm{~cm}$ alt.; caule quadrangular ramificado na base, ramos cilíndricos. Folhas simples, verticiladas; lâmina ca. 7,6 × $2,1 \mathrm{~cm}$, oblongo-lanceolada, ápice acuminado, margem denteada, base atenuada. Espigas, ca. 9,3 cm compr., terminais. Flores zigomorfas, sésseis; cálice gamossépalo, ca. $6 \mathrm{~mm}$ compr., sépalas 5; corola gamopétala, arroxeada, pétalas 5 , ca. 1,2 cm compr.; androceu e gineceu inclusos; filetes recobertos por tricomas, anteras ca. $0,7 \mathrm{~mm}$ compr.; ovário súpero, carpelos 2. Fruto não visto.

Material examinado: Boa Vista, Fazenda Salambaia, 3.X.2010, fl., E.A. Lima 43 (ACAM, EAN).

Stachytarpheta elatior apresenta ampla distribuição na América Tropical, ocorrendo associada a áreas úmidas e pantanosas. Espécie nativa do Brasil amplamente distribuída nas regiões Nordeste e Sudeste (Amaral et al. 2008). Encontrada florida em outubro. Caracteriza-se por apresentar caule quadrangular ramificado na base, além de inflorescências do tipo espiga, terminais, e pela corola arroxeada. 


\section{Agradecimentos}

Ao CNPq (Conselho Nacional de Desenvolvimento Científico e Tecnológico), o financiamento do projeto "Flora Vascular de Ambientes Rochosos no Semiárido Paraibano Nordeste do Brasil: Diversidade, Distribuição e Conservação" (Proc. no 562146/2010-5) e a Bolsa de Produtividade em Pesquisa concedidos a J.I.M. Melo. À Pró-Reitoria de Pós-Graduação e Pesquisa da Universidade Estadual da Paraíba (PRPGP/ UEPB), a concessão de auxílio financeiro a J.I.M. Melo ao projeto "Flora Vascular da APA do Cariri, Paraíba, Nordeste do Brasil" através do Edital 02/2010 - Programa de Incentivo à Pós-Graduação e Pesquisa (PROPESQ - Proc. no 2011/057). À Kyria Kogiso, o auxílio nos trabalhos de campo. À Macelly Medeiros, a ajuda no processamento dos espécimes no Laboratório de Botânica. A Alanne Rayssa e Renalle Ruana, a confecção das ilustrações. Aos revisores anônimos, as valiosas sugestões feitas ao manuscrito.

\section{Referências}

Adams, C.D. 1994. Cyperus (Cyperaceae). In: Davidse, G.; Souza, M.S. \& Chater, A.O. (eds.). Flora Mesoamericana 6: 404-422.

Agostinho, A.A.; Thomaz, S.M. \& Gomes, L.C. 2005. Conservação da biodiversidade em águas continentais do Brasil. Magadiversidade 1: 70-78.

Alves, J.J.A. 2007. Geoecologia da caatinga no semiárido do Nordeste brasileiro. Climatologia e Estudos da Paisagem 2: 58-71.

Alves-Araújo, A. \& Maciel, J.R. 2009. Hydrocharitaceae. In: Alves, M.; Araújo, M.F.; Maciel, J.R. \& Martins, S. (orgs.). Flora de Mirandiba. Associação Plantas do Nordeste, Recife. Pp. 177-178.

Alves, M.V.; Araújo, A.C.; Prata, A.N.; Vitta, F.; Hefler, S.; Trevisan, R.; Gil, A.S.B.; Martins, S. \& Thomas, W. 2009. Diversity of Cyperaceae in Brazil. Rodriguésia 60: 771-782.

Amaral, M.C.E. 2013. Nymphaeaceae. In: Lista de espécies da flora do Brasil (Forzza, R.C. et al., orgs.). Disponível em <http://floradobrasil.jbrj. gov.br/jabot/floradobrasil/FB10938>. Acesso em 28 Ago 2012.

Amaral, M.C.E.; Bittrich, V.; Faria, A.D.; Anderson, L.O. \& Aona, L.Y.S. 2008. Guia para plantas aquáticas e palustres do estado de São Paulo. Holos, Ribeirão Preto. 452 p.

Anderson, L.O. \& Amaral, M.C. 2005. Menyanthaceae. In: Wanderley, M.G.L.; Shepherd, G.J.; Melhem, T.S.; Martins, S.E.; Kirizawa, M. \& Giulietti, A.M. (eds.). Flora fanerogâmica do estado de São Paulo. Vol. 4. FAPESP/Rima, São Paulo. Pp. 277-278.
Andrade-Lima, D. 1981. The caatingas dominium. Revista Brasileira de Botânica 4: 149-153.

APG (Angiosperm Phylogeny Group) III. 2009. An update of the Angiosperm Phylogeny Group classification for the orders and families of flowering plants: APG III. Botanical Journal of the Linnean Society 161: 105-121.

Araújo, A.C. \& Longhi-Wagner, H.M. 1996. Levantamento taxonômico de Cyperus L. subg. Anosporum (Nees) Clarke (Cyperaceae-Cyperae) no RS, Brasil. Acta Botanica Brasilica 10: 153-192.

Barbosa, M.R.V.; Lima, J.R.; Cunha, J.P.; Agra, M.F. \& Thomas, W.W. 2007. Vegetação e flora no Cariri Paraibano. Oecologia Brasiliensis 11: 313-322.

Barros, M. 1960. Las Cyperáceas del estado de Santa Catalina. Sellowia 12: 181-450.

Bove, C.P.; Gil, A.S.B.; Moreira, C.B. \& Barros, A.R.F. 2003. Hidrófitas fanerogâmicas de ecossistemas aquáticos temporários da planície costeira do estado do Rio de Janeiro, Brasil. Acta Botanica Brasilica 17: 119-135.

Camargo, A.F.M.; Pezzato, M.M. \& Henry-Silva, G.G. 2003. Fatores limitantes a produção primária de macrófitas aquáticas. In: Thomaz, S.M. \& Bini, L.M. (eds.). Ecologia e manejo de macrófitas aquáticas. EDUEM, Maringá. Pp. 59-84.

Campelo, M.J.A.; Siqueira-Filho, J.A.; Cotarelli, V.M.; Souza, E.B. \& Pott, V.J. 2012. Macrófitas aquáticas nas áreas do projeto de integração do rio São Francisco. In: Siqueira-Filho, J.A. (ed.). Flora das caatingas do rio São Francisco: história natural e conservação. Andrea Jakobsson Estúdio Editorial, Rio de Janeiro. Pp. 193-229.

Chen, S.H.; Weng, S.H. \& Wu, M.J. 2009. Cyperus surinamensis Rottb., a newly naturalized sedge species in Taiwan. Taiwana 54: 399-402.

Cook, C.D.K. 1996. Water plants of the world. SPB Academic Publishing, Amsterdam. 902p.

Fidalgo, O. \& Bononi, V.L.R. 1989. Técnicas de coleta, preservação e herborização de material botânico. Instituto de Botânica, São Paulo (Série Documentos). 62p.

Forzza, R.C.; Leitman, P.M.; Costa, A.F.; Carvalho-Jr, A.A.; Peixoto, A.L.; Walter, B.M.T.; Bicudo, C.; Zappi, D.C.; Costa, D.P.; Lleras, E.; Martinelli, G.; Lima, H.C.; Prado, J.; Stehmann, J.R.; Baumgratz, J.F.A.; Pirani, J.R.; Sylvestre, L.; Maia, L.C.; Lohmann, L.G.; Queiroz, L.P.; Silveira, M.; Coelho, M.N.; Mamede, M.C.; Bastos, M.N.C.; Morim, M.P.; Barbosa, M.R.; Menezes, M.; Hopkins, M.; Secco, R.; Cavalcanti, T.B. \& Souza, V.C. (orgs.). 2012. Lista de espécies da flora do Brasil. Jardim Botânico do Rio de Janeiro, Rio de Janeiro. Disponível em $<$ http:// floradobrasil.jbrj.gov.br/>. Acesso em 31 Ago 2012.

Gil, A.S.B. \& Bove, C.P. 2007. Eleocharis R. Br. (Cyperaceae) no estado do Rio de Janeiro, Brasil. Biota Neotropica 7: 163-193. 
Gomes, V.S. 2000. Levantamento das Espécies de Pontederiaceae Kunth Nativas do Brasil. Dissertação de Mestrado. Universidade Federal de Pernambuco, Recife. 102p.

Guaglianone, R. 1996. Cyperaceae. In: Zuloaga, F.O. \& Morrone, O. (eds.). Catálogo de las plantas vasculares de la República Argentina. Pteridophyta, Gymnospermae e Angiospermae (Monocotyledonae). Missouri Botanical Garden, Saint Louis. Disponível em <http://www.darwin.edu.ar/Publicaciones/ CatalogoVascII/CatalogoVascII.asp $>$. Acesso em 29 Ago 2012.

Haynes, R.R. \& Holm-Nielsen, L.B. 1994. The Alismataceae. In: Flora Neotropica. Monograph 64. The New York Botanical Garden, New York. Pp. 1-112.

Haynes, R.R. \& Holm-Nielsen, L.B. 1992. The Limnocharitaceae. In: Flora Neotropica. Monograph 56. The New York Botanical Garden, New York. Pp. 1-34.

Hefler, S.M. \& Longhi-Wagner, H.M. 2012. Cyperus L. subg. Cyperus (Cyperaceae) na Região Sul do Brasil. Flora Ilustrada do Rio Grande do Sul. Revista Brasileira de Biociências 10: 327-372.

Henry-Silva, G.G.; Moura, S.T. \& Dantas, L.L.O. 2010. Richness and distribution of aquatic macrophytes in Brazilian semi-arid aquatic ecosystems. Acta Limnologica Brasiliensia 22: 147-156.

Irgang, B.E. \& Gastal Jr., C.V.S. 1996. Macrófitas aquáticas da Planície Costeira do RS. Universidade Federal do Rio Grande do Sul, Porto Alegre. 289p.

Leite, R.L. 2001. Influência de macrófitas aquáticas sobre a qualidade da água de açudes do semi-árido da Paraíba. Dissertação de Mestrado. Universidade Federal da Paraíba, João Pessoa. 129p.

Lorenzi, H. 2006. Manual de identificação e controle de plantas daninhas: plantio direto e convencional. Instituto Plantarum, Nova Odessa. 339p.

Luceño, M.; Alves, M.V. \& Mendes, A.P. 1997. Catálogo florístico y claves de identificación de las cyperáceas de los estados de Paraíba y Pernambuco (Nordeste del Brasil). Annales del Jardín Botánico de Madrid 55: 67-100.

Martins, M.; Carvalho-Okano, R. \& Luceño, M. 1999. Cyperaceae do Parque Estadual Paulo César Vinha, Guarapari, Espírito Santo, Brasil. Acta Botanica Brasilica 13: 187-222.

Martins, D.; Costa, N.V.; Terra, M.A. \& Marchi, S.R. 2008. Caracterização da comunidade de plantas aquáticas de dezoito reservatórios pertencentes a cinco bacias hidrográficas do estado de São Paulo. Planta Daninha 26: 17-32.

Matias, L.Q.;Amado, E.R. \& Nunes, E.P. 2003. Macrófitas aquáticas da lagoa de Jijoca de Jericoacoara, Ceará, Brasil. Acta Botanica Brasilica 4: 623-631.

Matias, L.Q. 2010. A Synopsis of Alismataceae from the Semi-Arid Region of Northeastern Brazil. Revista Caatinga 23: 46-53.
Matias, L.Q.; Sakuragui, C.M. \& Lopes, R.C. 2013. Alismataceae. In: Lista de espécies da flora do Brasil. Disponível em $<$ http://floradobrasil.jbrj. gov.br/jabot/floradobrasil/FB15386>. Acesso em 28 Ago 2012.

Moraes, A.O.; Melo, E.; Agra, M.F. \& França, F. 2009. A família Solanaceae nos "Inselbergues" do semiárido da Bahia, Brasil. Iheringia, Série Botânica 64: 109-122.

Moreira, E.R.F. 1988. Mesorregiões e microrregiões da Paraíba, delimitação ecaracterização. GAPLAN, João Pessoa. $74 \mathrm{p}$.

Moura-Júnior, E.G.; Lima, L.F.; Silva, S.S.L.; Paiva, R.M.S.; Ferreira, F.A.; Zickel, C.M. \& Pott, A. 2013. Aquatic macrophytes of Northeastern Brazil: checklist, richness, distribution and life forms. Checklist 9: 298-312.

Paraíba. Superintendência de Desenvolvimento e Meio Ambiente. Áreas Protegidas e Unidades de Conservação. Disponível em $<$ http://www.sudema.pb.gov.br/index. php?option $=$ com_content $\&$ view $=$ article $\&$ id $=724>$. Acesso em 27 Jul 2012.

Pivari, M.O.; Pott, V.J. \& Pott, A. 2008a. Macrófitas aquáticas de ilhas flutuantes (baceiros) nas subregiões do Abobral e Miranda, Pantanal, MS, Brasil. Acta Botanica Brasilica 22: 563-571.

Pivari, M.O.D.; Salimena, F.R.G.; Pott, V.J. \& Pott, A. 2008b. Macrófitas aquáticas da lagoa Silvana, Vale do Rio Doce, Minas Gerais, Brasil. Acta Botanica Brasilica 22: 563-571.

Pott, V.J. \& Cervi, A.C. 1999. A família Lemnaceae Gray no Pantanal (Mato Grosso e Mato Grosso do Sul), Brasil. Revista Brasileira de Botânica 22: 153-174.

Sakuragui, C.M. \& Lopes, R.C. 2013. Hydrocleys. In: Lista de espécies da flora do Brasil (Forzza, R.C. et al., orgs.). Disponível em $<$ http://floradobrasil. jbrj.gov.br/jabot/floradobrasil/FB102843>. Acesso em 28 Ago 2012.

Scremin-Dias, E.; Pott, V.J.; Hora, R.C. \& Souza, P.R. 1999. Nos jardins da Bodoquena: guia para identificação de plantas aquáticas de Bonito e região. Ed. UFMS, Campo Grande. 160p.

Silva, C.J. 1981. Observações sobre a biologia reprodutiva de Pistia stratiotes L. Acta Amazonica 11: 487-504.

Silva, G.A.R. \& Santos, J.U.M. 2010. Novos registros de espécies da subtribo Ecliptinae (Heliantheae - Asteraceae) para a Amazônia brasileira. Acta Amazonica 40: 499-508.

Silveira, G.H. \& Longhi-Wagner, H.M. 2008. Cyperaceae Juss. no Morro Santana - Porto Alegre e Viamão, Rio Grande do Sul, Brasil. Iheringia, Série Botânica 63: 295-320.

Souza, B.I.; Suertegaray, D. \& Lima, E.R.V. 2010. Políticas públicas, uso do solo e desertificação nos Cariris Velhos (PB/Brasil). Scripta Nova: Revista Electrónica de Geografía y Ciencias Sociales 311: 26-29. 
Souza, V.C. \& Giulietti, A.M. 2009. Levantamento das espécies de Scrophulariaceae sensu lato nativas do Brasil. Pesquisas, Botânica 60: 7-288.

Thiers, B. 2010. Index herbariorum: a global directory of public herbaria and associated staff. New York Botanical Garden's Virtual Herbarium. Disponível em $<$ http://sweetgum.nybg.org/ih/>. Acesso em 28 Jul 2012.

Trevisan, R. \& Boldrini, I.I. 2008. O gênero Eleocharis R. Br. (Cyperaceae) no Rio Grande do Sul, Brasil. Revista Brasileira de Biociências 6: 7-67.

Trindade, R.R.T.; Pereira, S.A.; Albertoni, E.F. \& PalmaSilva, C. 2010. Caracterização e importância das macrófitas aquáticas com ênfase nos ambientes límnicos do Campus Carreiros - FURG, Rio Grande, RS. Cadernos de Ecologia Aquática 5: 1-22.

Tropicos. org. Missouri Botanical Garden. Disponível em <http://tropicos.org>. Acesso em 30 Ago 2012.

Velloso, A.L.; Sampaio, E.V.S.B. \& Pareyn, F.G.C. 2002. Ecorregiões propostas para o Bioma Caatinga. APNE/Instituto de Conservação Ambiental/The Nature Conservancy do Brasil, Recife. 75p.

Zardini, E.M. \& Raven, P.H. 1997. Onagraceae. In: Rizzo, J.A. (coord.). Coleção Rizzo - Flora dos estados de Goiás e Tocantins. Vol. 20. Editora da Universidade Federal de Goiás, Goiânia. 87p. 